7. Reprod. Fertil. (1963) 5, 109-122

\title{
SEMEN COMPOSITION AND METABOLISM IN THE STALLION AND JACKASS
}

\author{
T. MANN, C. S. MINOTAKIS* AND C. POLGE \\ A.R.C. Unit of Reproductive Physiology and Biochemistry, School of Veterinary Medicine, \\ and Molteno Institute, University of Cambridge
}

(Received 30th August 1962)

\begin{abstract}
Summary. Stallion and jackass semen have several chemical characteristics in common, such as ergothioneine, which originates chiefly in the ampullae, and citric acid, which is derived from the seminal vesicles; the vesicular secretion also contains an extraordinarily high concentration of lactic acid. In both species the semen is ejaculated in the form of a 'pre-sperm', 'sperm-rich' and 'post-sperm' fraction, represented by the urethral, ampullar and vesicular contributions, respectively. Stallion and jackass semen are practically free from fructose, but the spermatozoa are able to metabolize added fructose anaerobically and aerobically. In the absence of oxygen, the rate of fructose conversion to lactic acid as well as sperm motility are very low; in the presence of oxygen, the rate of fructose disappearance, as well as motility, are much higher. In this and other respects, stallion and jackass spermatozoa resemble those of the boar, but differ from human, ram and bull spermatozoa. An easily oxidizable substance occurs in the seminal plasma of both the jackass and stallion, like in the boar; this substance is responsible for the plasma's own oxygen uptake.

Stallion and jackass semen differ from each other with respect to the rate of aerobic metabolism, and sperm survival in vitro. Exogenous substrates increase the oxygen uptake of jackass spermatozoa more than that of the stallion spermatozoa. The motility and respiratory activity in jackass semen diluted with an egg-yolk medium are maintained at $5^{\circ} \mathrm{C}$ much longer than in stallion semen.
\end{abstract}

\section{INTRODUCTION}

Previous studies have shown that stallion semen contains ergothioneine which is derived mostly from the ampullae; citric acid which is secreted by the seminal vesicles; glycerylphosphorylcholine which is largely contributed by the epididymides; and some sorbitol, but very little fructose (Dawson, Mann \& White, 1957; King \& Mann, 1959; Leone, 1954; Mann, Leone \& Polge, 1956; Mann, Short, Walton, Archer \& Miller, 1957). Comparative studies on the semen of a closely related species, the jackass, have not been conducted so far, nor has

* Present address: Animal Breeding Research Station, Iera odos.-Votanikos kipos, Athens, Greece. 
there been any systematic attempt to study either stallion or jackass semen with respect to fructolysis and respiration, especially in relation to sperm motility. Observations pertaining to these problems are reported in the present study.

\section{MATERIALS AND METHODS}

\section{SEMEN}

Two Welsh pony stallions, S1 and S2, 2 and 5 years old, and two jackasses, J1 and $\mathrm{J} 2,10$ and 12 years old, were used. The semen was collected by artificial vagina during the period between the beginning of November and the end of February. Sperm counts were made by diluting the semen suitably with saline solution containing $3 \%$ formaldehyde, and determining the concentration of spermatozoa in a haemocytometer. Motility was observed by placing a drop of semen between a slide and cover glass and examining it microscopically with a $\times 40$ objective at $37^{\circ} \mathrm{C}$. Motility scores were ascribed to each sample on an arbitrary scale, similar to that used by Aalbers, Mann \& Polge (1961) in their investigation of boar semen, and are expressed by two values, the first of which gives the proportion of spermatozoa showing any kind of motility, scored on a scale of 0 to 10 , and the second refers to the proportion of spermatozoa that were showing progressive movement, and this is scored also on a scale of 0 to 10 .

In several experiments, a fractional collection of semen was carried out by the 'split-ejaculate method', aimed at securing a 'pre-sperm', 'sperm-rich' and 'post-sperm' portion of the ejaculate. In most of the incubation experiments, 500 units $/ \mathrm{ml}$ penicillin and 500 units/ml streptomycin were included. The seminal plasma was obtained from semen by centrifugation.

\section{ANALYTICAL METHODS}

\section{Deproteinization}

This was usually carried out by three methods. One 3-ml sample of semen was diluted with $9 \mathrm{ml}$ water, and deproteinized directly with $3 \mathrm{ml} 0.3 \mathrm{~N}-\mathrm{Ba}$ $(\mathrm{OH})_{2}$ and $3 \mathrm{ml} 5 \% \mathrm{ZnSO}_{4} \cdot 7 \mathrm{H}_{2} \mathrm{O}$; the centrifuged extract was used for determinations of fructose, lactic acid, chloride, and sometimes also for ergothioneine. Another 2-ml sample was treated with $12 \mathrm{ml}$ ethanol, centrifuged, the precipitate discarded, the supernatant solution concentrated to about $1 \mathrm{ml}$, deproteinized with $0.5 \mathrm{ml} 0.3 \mathrm{~N}-\mathrm{Ba}(\mathrm{OH})_{2}$ and $0.5 \mathrm{ml} 5 \% \mathrm{ZnSO}_{4} \cdot 7 \mathrm{H}_{2} \mathrm{O}$, brought with water to exactly $4 \mathrm{ml}$, centrifuged, and the water-clear solution used for determination of ergothioneine. A third 2-ml sample was diluted with $2 \mathrm{ml}$ water and deproteinized with $2 \mathrm{ml} \mathrm{50 \%}$ trichloroacetic acid, left standing in the cold overnight, and centrifuged; the extract was used for the determination of acid-soluble phosphorus (after wet incineration with perchloric acid) and citric acid; a slight cloudiness of the extracts did not interfere with citric acid determinations; strongly opalescent extracts were treated with more trichloroacetic acid, and sulphuric acid.

\section{Chemical determinations}

Fructose was determined as described by Mann (1946, 1948), lactic acid according to Barker \& Summerson (1941; cf. Umbreit, Burris \& Stauffer, 1957); 
ergothioneine and citric acid according to Mann et al. (1957); and total acidsoluble phosphorus, in trichloroacetic acid extracts according to King (1946). Chloride determinations were carried out in barium-zinc extracts; 2- or 4-ml samples were diluted with water to $10 \mathrm{ml}$, treated with $5 \mathrm{ml} 0.02 \mathrm{~N}-\mathrm{AgNO}_{3}$ and $5 \mathrm{ml}$ concentrated nitric acid; the mixture was left standing for about $5 \mathrm{~min}$ and was titrated, in the presence of $0.3 \mathrm{~g}$ powdered ferric alum, with 0.02 $\mathrm{N}-\mathrm{NH}_{4}$ CNS.

\section{Fructolysis}

Anaerobic, as well as aerobic fructolysis was measured by following the disappearance of fructose and the formation of lactic acid, in samples buffered with phosphate, and incubated at $37^{\circ} \mathrm{C}$. The details of the procedure were similar to those employed by Aalbers $e t$ al. (1961) for their study of fructolysis in boar semen.

The anaerobic incubations were carried out in Thunberg tubes filled with nitrogen, and the aerobic incubations under similar conditions but in the presence of air. The main compartment of each tube contained 2 to $3 \mathrm{ml}$ of either whole semen or 'sperm-rich' fraction (the middle portion of an ejaculate), or spermatozoa concentrated by centrifugation. The side-bulb of the Thunberg

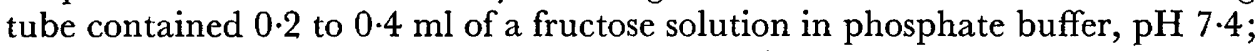
the final concentration of fructose, after mixing the contents of the main compartment and side-bulb, varied in different experiments, from 0.2 to $1 \%$. Motility observations, and fructose and lactic acid determinations, were carried out at the beginning, and after 1, 2 and $3 \mathrm{hr}$, of incubation.

The results of fructolysis measurements were expressed in terms of the fructolysis index, FI $=\mathrm{mg}$ fructose utilized, or lactic acid produced, by $10^{9}$ spermatozoa, in $1 \mathrm{hr}$, at $37^{\circ} \mathrm{C}$.

\section{Respiration}

The oxygen consumption was measured at $37^{\circ} \mathrm{C}$, in Barcroft's differential manometers filled with air, in the presence of potassium hydroxide as the carbon dioxide-absorbing agent. Results were expressed as $\mathrm{Z}_{\mathrm{O}_{2}}=\mu \mathrm{l} \mathrm{O}_{2}$ consumed by $10^{8}$ spermatozoa, in $1 \mathrm{hr}$ at $37^{\circ} \mathrm{C}$.

\section{RESULTS}

GENERAL CHARACTERISTICS OF STALLION AND JACKASS SEMEN

Table 1 lists the results obtained by analysis of whole semen in the stallions, S1 and S2, and jackasses, J1 and J2. From these results it can be seen that the composition of semen varied not only between the individual animals, but also in the same animal. In part, this may have been due to seasonal variations and differences in age; one of the stallions in particular (S1), was a very young animal, which produced consistently rather small quantities of semen. Another contributing factor may have been a fluctuating ratio between the different fractions which compose the normal ejaculate, and in particular, the extent to which the 'post-sperm' fraction contributed to the make-up of the whole ejaculate. 
The level of fructose in semen as determined colorimetrically by the resorcinol reaction, was low in the stallion and jackass alike, namely, 1.76 to $3.83 \mathrm{mg} / 100$ $\mathrm{ml}$. Moreover, the resorcinol reaction remained positive after incubation of samples of plasma (either whole or after deproteinization) with yeast, as described by Mann (1946). It is, therefore, doubtful whether stallion or jackass semen do, in fact, normally contain more than a trace of yeast-fermentable,

\section{TABLE 1}

SOME GHARACTERISTICS OF STALLION AND JAGKASS SEMEN

\begin{tabular}{|c|c|c|}
\hline & Stallion semen & Jackass semen \\
\hline Volume of ejaculate (mI) & $\begin{array}{lll}\text { S1 [ }[9]: & 13 \cdot 5 & (6 \text { to } 23) \\
\text { S2 [11] } & 39 \cdot 7 & (23 \text { to } 57)\end{array}$ & $\begin{array}{lll}\mathrm{J} 1[13]: & 42 \cdot 1 & (17 \text { to } 67) \\
\mathrm{J} 2[14]: & 69 \cdot 1 & (36 \text { to } 120)\end{array}$ \\
\hline Motile spermatozoa $(\%)$ & $\begin{array}{lll}\text { S1 [ } 9]: & 77 \cdot 0 & (70 \text { to } 90) \\
\text { S2 [11] } & 74 \cdot 2 & (60 \text { to } 90)\end{array}$ & 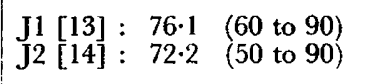 \\
\hline $\begin{array}{l}\text { Sperm density } \\
\text { (million cells/ml) }\end{array}$ & $\begin{array}{ll}\text { S1 }[9]: 169 & (100 \text { to } 250) \\
\text { S2 }[7]: 173 & (100 \text { to } 220)\end{array}$ & $\begin{array}{l}\mathrm{J} 1[13]: 222 \\
\mathrm{~J} 2[11]: 229\end{array}$ \\
\hline Fructose $(\mathrm{mg} / 100 \mathrm{ml})$ & $\mathrm{S} 1[3]: \quad 2.07(1.76$ to 2.64$)$ & $\begin{array}{ll}\mathrm{JI}[\mathrm{4}]: & 3.20(1.83 \text { to } 3.83) \\
\mathrm{J} 2[\mathrm{2}]: & 2.89(1.99 \text { to } 3.80)\end{array}$ \\
\hline Lactic acid $(\mathrm{mg} / 100 \mathrm{ml})$ & $\mathrm{S} 2[2]: 20.59(12.09$ to $29 \cdot 10)$ & $\mathrm{J} 2[5]: 44.37(22.3$ to 77.4$)$ \\
\hline Ergothioneine $(\mathrm{mg} / 100 \mathrm{ml})$ & $\begin{array}{ll}\text { S1 [ } 3]: & 3.33(2.08 \text { to } 4.00) \\
\text { S2 [ 1]: } & 2 \cdot 06\end{array}$ & $\begin{array}{ll}\mathrm{J} 1[4]: & 6 \cdot 76(4.0 \text { to } 8 \cdot 2) \\
\mathrm{J} 2[\mathrm{4}]: & 3.39(1.95 \text { to } 4 \cdot 98)\end{array}$ \\
\hline Gitric acid $(\mathrm{mg} / 100 \mathrm{ml})$ & $\mathrm{S} 1[3]: \quad 1.79(1.7$ to 2.6$)$ & 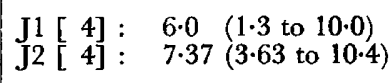 \\
\hline Chloride (mg NaCl $/ 100 \mathrm{ml}$ ) & SI [ 3]: 726 & $\begin{array}{l}\mathrm{J} 1[4]: 730 \\
\mathrm{~J} 2[4]: 757\end{array}$ \\
\hline $\begin{array}{l}\text { Acid-soluble phosphorus } \\
(\mathrm{mg} / 100 \mathrm{ml})\end{array}$ & - & $\mathrm{J} 2[2]: 19 \cdot 7 \quad(17 \cdot 9$ to $21 \cdot 6)$ \\
\hline
\end{tabular}

Results are expressed as averages; range is given in parentheses; number of ejaculates used for analysis is given in brackets; stallions: $\mathrm{S} 1$ and $\mathrm{S} 2$; jackasses: $\mathrm{J} 1$ and $\mathrm{J} 2$.

free fructose. The values for lactic acid on the other hand, were consistently high, the average being $20.59 \mathrm{mg} / 100 \mathrm{ml}$ in the stallion, and $44.37 \mathrm{mg} / 100 \mathrm{ml}$ in jackass semen; the highest value encountered in the latter species was 77.4 $\mathrm{mg} / 100 \mathrm{ml}$.

GOMPOSITION OF SUGCESSIVE SEMINAL FRAGTIONS IN THE ORDER OF APPEARANCE DURING EJACULATION

The sequence with which the various chemical components of semen normally appear in the stallion ejaculate has been described previously (Mann et al., $1956,1957)$; the present study in this respect was therefore, confined to the jackass. Two experiments are reported, in which fractions were collected during ejaculation in flasks exchanged at intervals of about 3 to $5 \mathrm{sec}$. 
Experiment No. 1

The results obtained in this experiment are illustrated in Text-fig. 1. Altogether five fractions were collected. Fraction $1(2.8 \mathrm{ml})$ which represents the initial or 'pre-sperm' portion of the ejaculate, consisted of a transparent fluid, watery in appearance, practically free from spermatozoa, ergothioneine and citric acid, but containing quite an appreciable quantity of lactic acid, 12 $\mathrm{mg} / 100 \mathrm{ml}$, and a high concentration of chloride, $510 \mathrm{mg} \mathrm{Cl} / 100 \mathrm{ml}$, corresponding to a content of $850 \mathrm{mg} \mathrm{NaCl} / 100 \mathrm{ml}$. These results were confirmed by analyses of two more 'pre-sperm' fractions, collected from the same animal, but on different occasions; the lactic acid content varied from 12 to $16 \mathrm{mg} / 100 \mathrm{ml}$,

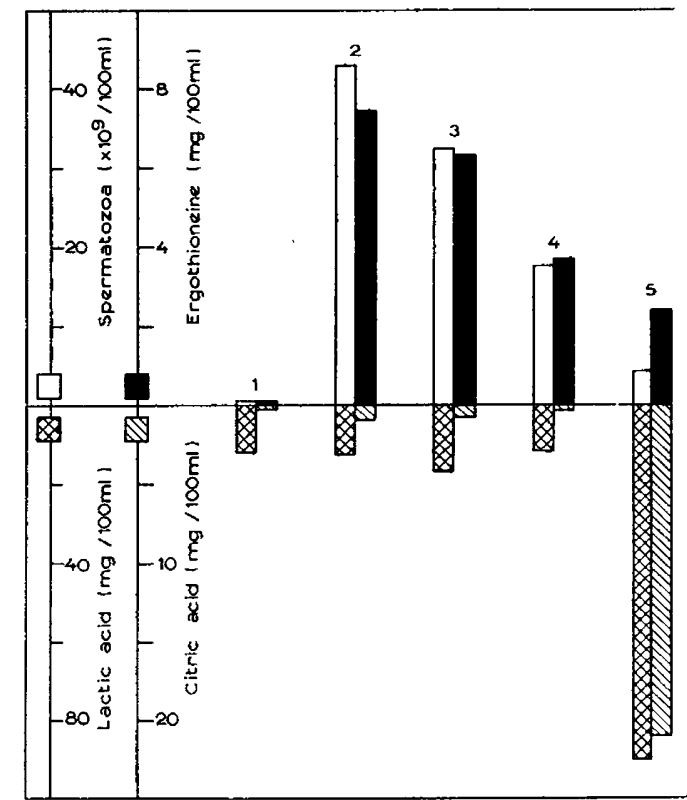

TeXT-Fig 1. Composition of jackass semen fractions, 1 to 5 , collected by the 'split-ejaculate method' at 3- to 5-sec intervals.

and that of chloride from 819 to $850 \mathrm{mg} \mathrm{NaCl} / 100 \mathrm{ml}$. Fraction $2(9 \mathrm{ml})$, collected immediately after the emission of the 'pre-sperm' fluid had ceased, represented, together with the next two fractions, $3(17 \mathrm{ml})$ and $4(9 \mathrm{ml})$, the main bulk of the 'sperm-rich' portion of the ejaculate. Fraction 2, however, had not only the highest sperm concentration, but at the same time the highest content of ergothioneine. That is only to be expected, since ergothioneine is derived mainly from the ampullar secretion (Leone, 1954), and as such, it accompanies the spermatozoa during ejaculation. The lactic acid content of the 'sperm-rich' Fraction 2 was about the same as that of the 'pre-sperm' Fraction 1, but its chloride content was distinctly lower, namely, $744 \mathrm{mg}$ $\mathrm{NaCl} / 100 \mathrm{ml}$. The three 'sperm-rich' fractions, 2 to 4 , were of a similar milky appearance, and had a slightly yellowish colour, and exhibited under the microscope, the 'wave' motion, which is characteristic of thick sperm suspension. All three fractions were almost entirely free from vesicular secretion, as shown 
by the very small admixture of citric acid, which originates in the seminal vesicles. They contained, on the other hand, some lactic acid, though not nearly as much as the 'post-sperm' Fraction 5, which represents chiefly the vesicular secretion. It had the characteristic 'glairy mucus' appearance of the seminal vesicle secretion and contained only a few spermatozoa; it was rich in citric acid $(21.5 \mathrm{mg} / 100 \mathrm{ml})$ and contained a remarkably high concentration of lactic acid, $89 \mathrm{mg} / 100 \mathrm{ml}$.

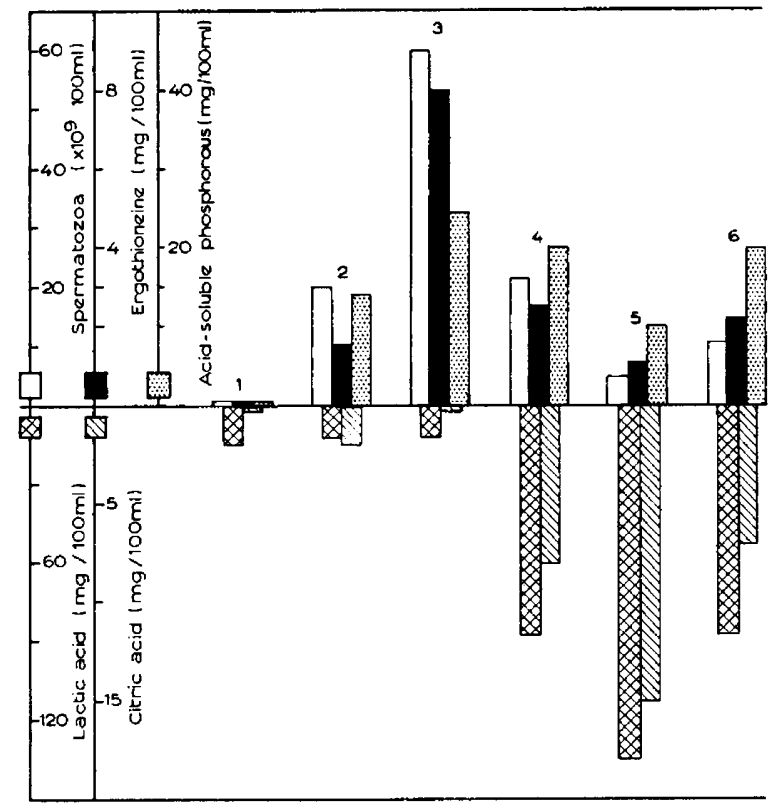

Text-Fig. 2. Composition of jackass semen fractions, 1 to 6 , collected by the 'splitejaculate method' at 3- to 5-sec intervals.

\section{Experiment No. 2}

This was essentially a repetition of the previous experiment, except that six, instead of five fractions, were collected: $1,10 \mathrm{ml} ; 2,25 \mathrm{ml} ; 3,2 \mathrm{ml} ; 4,19 \mathrm{ml}$; $5,27 \mathrm{ml}$; and 6,38 ml. The results of this experiment are illustrated in Text-fig. 2. It can be seen that Fraction I again had all the characteristics of the watery 'pre-sperm' fluid which precedes the emission of the 'sperm-rich' portion of the ejaculate; it was sperm-free, and had no ergothioneine or citric acid, but contained some lactic acid $(14 \mathrm{mg} / 100 \mathrm{ml})$ and a large amount of chloride $(819 \mathrm{mg}$ $\mathrm{NaCl} / 100 \mathrm{ml}$ ). Fractions 2 and 3 represented the 'sperm-rich' portion, and Fraction 4 must have been a mixture of the 'sperm-rich' and 'post-sperm' fractions, since, in addition to spermatozoa and ergothioneine, it also contained quite a large admixture of citric acid. Fraction 5 consisted mainly of the vesicular secretion as can be seen from the high citric acid content and a remarkably high content of lactic acid which was much higher than that encountered in any of the preceding fractions. Fraction 6 was of exceptional interest since it contained more spermatozoa and ergothioneine, but less citric acid and lactic acid, than the preceding Fraction 5. It seems that Fraction 6 
must have been formed as the result of a second 'ejaculatory wave', and constituted as it were, a second ejaculate, following closely on the first. A phenomenon of this kind has been previously encountered, and studied chemically, in the boar, but not in either the stallion or the jackass. Acid-soluble phosphorus was also examined in all six fractions, 1 to 6 . As can be seen from Text-fig. 2, the acid-soluble phosphate accompanied in general, the spermatozoa. That is only to be expected, since acid-soluble phosphorus of the seminal plasma is due largely to glycerylphosphorylcholine, a substance which is produced in the epididymis.

METABOLISM OF SEMEN, IN RELATION TO SPERM MOTILITY AND SURVIVAL

Anaerobic and aerobic fructolysis, as well as respiration, have been studied in both stallion and jackass semen.

\section{Anaerobic fructolysis}

The rate at which fructose disappeared anaerobically from sperm samples incubated at $37^{\circ} \mathrm{C}$ in vitro was low; in the jackass, however, it was somewhat higher than in the stallion. Although considerable fluctuations were noted even in the same animal, Fi did not exceed the low level, which is also typical of the boar. We have not observed either with stallion or jackass spermatozoa, fructolytic activity of the magnitude typical of the bovine, ram, or human spermatozoa. Another feature of the anaerobic metabolism, especially in the stallion, was the rapid decline in the rate of sperm fructolysis which often set in during the $2 \mathrm{nd} \mathrm{hr}$ of incubation at $37^{\circ} \mathrm{G}$, and was from then onwards progressive. The over-all ranges within which FI fluctuated in the eight experiments conducted with anaerobically incubated sperm samples, were as follows. In the jackass: 1st hr, 0.082 to $0.229 ; 2 \mathrm{nd} \mathrm{hr}, 0.040$ to $0.171 ; 3 \mathrm{rd} \mathrm{hr}, 0.040$ to 0.115 ; in the stallion: $1 \mathrm{st} \mathrm{hr}, 0.024$ to $0.134 ; 2 \mathrm{nd} \mathrm{hr,} 0.0$ to $0.086 ; 3 \mathrm{rd} \mathrm{hr,} 0.0$. Parallel with fructolysis, motility in the anaerobically-incubated samples was observed to decline rapidly. The ranges of 'motility scores' during the 1st, 2nd, and $3 \mathrm{rd} \mathrm{hr}$ of incubation were, respectively, in the jackass: $3 / 2$ to $4 / 3,0 \cdot 5 / 0$ to $2 / 1$, and $1 / 0 \cdot 5$ to $1 / 1$; and in the stallion: $1 / 0 \cdot 5$ to $4 / 3,0 / 0$ to $2 / 0 \cdot 5$, and $0 / 0$. When the rate of anaerobic disappearance of fructose was compared with the rate of lactic acid formed, it was noted that the amount of lactic acid accumulating anaerobically was usually 10 to $30 \%$ less than that expected to have arisen from a direct and complete glycolytic breakdown of fructose. The reason for that phenomenon remains to be explored in the future, with the possibility in mind that during the anaerobic fructolysis, products other than lactic acid are accumulating, such as for example, pyruvic acid or methylglyoxal.

\section{Aerobic fructolysis}

Jackass and stallion spermatozoa were capable of metabolizing fructose much more efficiently under aerobic than anaerobic conditions; the higher rate of aerobic fructolysis also corresponded to a much higher degree of motility, and much longer sperm survival. Whereas anaerobically stallion spermatozoa showed during the $3 \mathrm{rd} \mathrm{hr}$ of incubation no signs of either fructolytic activity $(F I=0)$ or motility (score $=0 / 0)$, in the air, even after $3 \mathrm{hr}$, sperm fructolysis 
and motility were still good ( $\mathrm{FI}=0.086$ to 0.140 ; motility score $=4 / 3$ to $6 / 5$ ). Similar behaviour, even more marked, has been observed in experiments with jackass spermatozoa. Two such experiments are illustrated in Text-figs. 3 and 4. In each of these two Text-figures, two sets of data are presented; on the left are the results obtained with whole semen, incubated anaerobically as well as aerobically; and on the right are shown the results obtained with concentrated sperm suspensions prepared from semen by centrifugation. This mode of presentation makes it possible to assess, at a glance, the damage to jackass spermatozoa, which results from centrifugation. This exceptional sensitivity to centrifugation is yet another characteristic which distinguishes the spermatozoa of jackass and stallion, from those of other domestic animals.

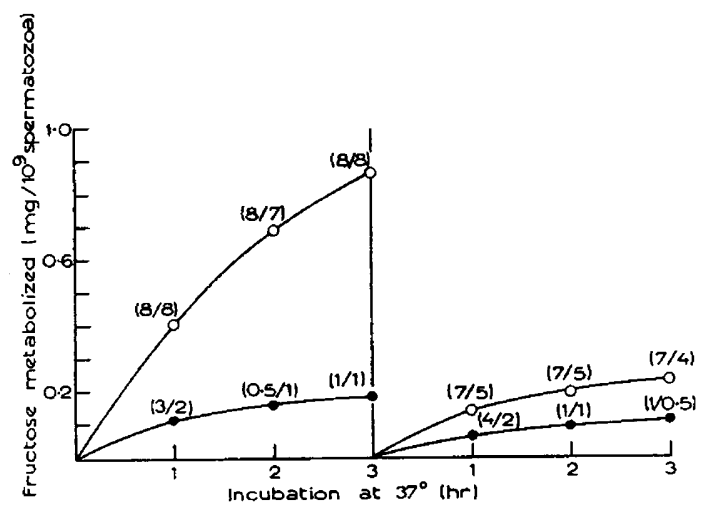

\begin{abstract}
TEXT-FIG. 3. Fructolysis in whole semen (left) and in a concentrated sperm suspension (right) of jackass $(\mathrm{Jl})$; - , anaerobic fructolysis; $\mathrm{O} \longrightarrow \mathrm{O}$, aerobic fructolysis; figures in parentheses indicate motility scores; the main compartment of the Thunberg tubes contained $2 \mathrm{ml}$ of either semen $\left(0.2 \times 10^{9}\right.$ spermatozoa/ml $)$ or of the concentrated sperm suspension $\left(0.37 \times 10^{9}\right.$ spermatozoa/ml $)$ obtained from semen by centrifugation

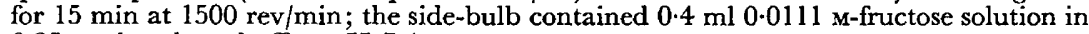
0.25 m-phosphate buffer, $\mathrm{pH} 7 \cdot 4$.
\end{abstract}

The experiment shown in Text-fig. 3 was carried out with whole jackass semen $\left(0.2 \times 10^{9}\right.$ spermatozoa $\left./ \mathrm{ml}\right)$ and with a concentrated sperm suspension $\left(0.37 \times 10^{9}\right.$ spermatozoa $\left./ \mathrm{ml}\right)$ obtained by centrifugation at $1500 \mathrm{rev} / \mathrm{min}$ for $15 \mathrm{~min}$. From the results presented in Text-fig. 3 , it has been calculated that the fructolytic activity of spermatozoa, covering the whole 3-hr period, was as follows: In whole semen, the anaerobic disappearance of fructose corresponded to $\mathrm{FI}=0.060$; aerobically, it was nearly five times higher, namely, FI $=0.283$. The amount of lactic acid which accumulated aerobically corresponded to FI $=0.155$, the difference 0.283 to $-0 \cdot 155=0.128$ being presumably due to the oxidative removal of part of the lactic acid by spermatozoa. In the concentrated sperm suspension, prepared from semen by centrifugation at 1500 $\mathrm{rev} / \mathrm{min}$, both the anaerobic and aerobic fructolysis were proceeding at a rate which was about $70 \%$ lower than that in whole semen.

The experiment presented in Text-fig. 4 was essentially a repetition of the one described above, except that a lower speed of centrifugation, namely, 1000 $\mathrm{rev} / \mathrm{min}$, was used for the preparation of the sperm suspension. In whole semen, the anaerobic disappearance of fructose corresponded to $\mathrm{FI}=0 \cdot 171$, 
and the aerobic one to $\mathbf{F I}=0.573$. In the concentrated sperm suspension prepared by centrifugation at $1000 \mathrm{rev} / \mathrm{min}$, the corresponding values were FI $=0.080$ and 0.398 , respectively. Motility, as might be expected, was much better under aerobic than anaerobic conditions.

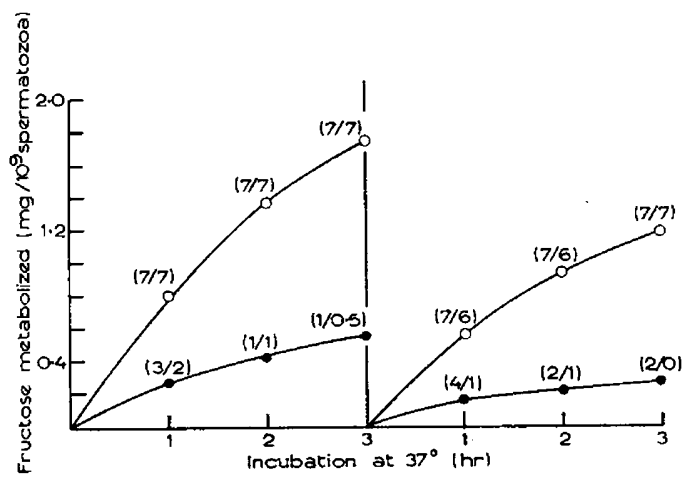

Texr-Fig. 4. Fructolysis in whole semen (left) and in a concentrated sperm suspension (right) of jackass (J2); -0 , anacrobic fructolysis; $0-0$, aerobic fructolysis; figures in parenthesis indicate motility scores; the main compartment of the Thunberg tubes contained $3 \mathrm{ml}$ of either semen $\left(0.17 \times 10^{9}\right.$ spermatozoa $\left./ \mathrm{ml}\right)$ or of the concentrated sperm suspension $\left(0.24 \times 10^{9}\right.$ spermatozoa/ml $)$ obtained from semen by centrifugation for $20 \mathrm{~min}$ at $1000 \mathrm{rev} / \mathrm{min}$; the side-bulb contained $0.2 \mathrm{ml} 0.0555 \mathrm{M}$-fructose solution in $0 \cdot 25$ m-phosphate buffer, pH $7 \cdot 4$

\section{Respiration and oxidizable substrates}

The oxygen uptake of stallion and jackass semen is due partly to spermatozoa, and partly to the seminal plasma. In that respect, again stallion and jackass semen resemble that of the boar. As in the boar, the 'extracellular respiration' of stallion and jackass semen is also considerably enhanced by the addition of phosphate buffer, and takes place mainly during the first 30 min of aerobic

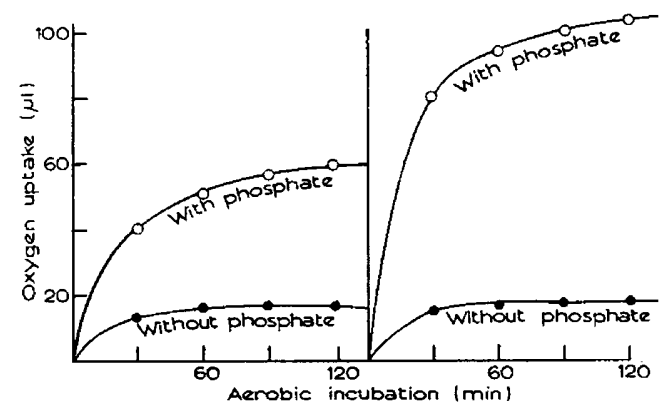

Text-Frg. 5. Oxygen uptake of $3 \mathrm{ml}$ seminal plasma of stallion (left) and jackass (right); with added phosphate $(0.5 \mathrm{ml} 0.25 \mathrm{M}$-sodium phosphate buffer, $\mathrm{pH} 7.4)$ and without added phosphate $(0.5 \mathrm{ml}$ Ringer solution).

incubation (Text-fig. 5). The presence of the oxidizable substance in the seminal plasma is probably responsible for the initial high rate of oxygen consumption which characterizes the semen as a whole. Whereas, however, the oxygen uptake of the seminal plasma is transient, that of the whole semen continues for much longer periods, and it is further enhanced, particularly in the jackass, by the addition of fructose (Text-fig. 6). 
In the experiment with jackass semen, illustrated by Text-fig. 6 , fructose disappearance and lactic acid formation were determined, in addition to the oxygen uptake. The amount of fructose which disappeared in $3 \mathrm{hr}$ from the aerobically incubated semen samples $\left(0.75 \times 10^{9}\right.$ spermatozoa $\left./ 3 \mathrm{ml}\right)$ was 0.516

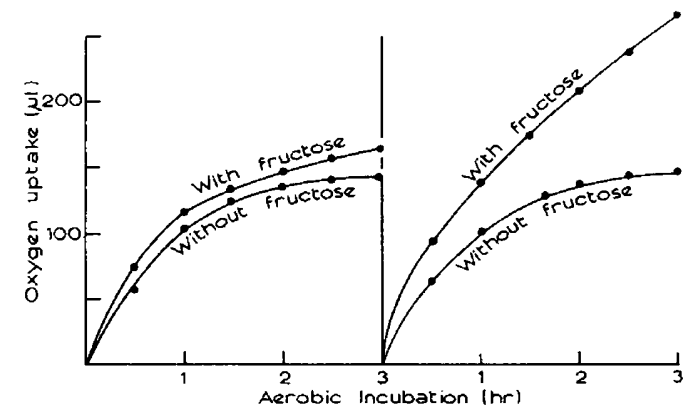

TeXT-Fig. 6. Effect of fructose on the oxygen uptake of semen from stallion (left) and jackass (right) $; 3 \mathrm{ml}$ stallion semen $\left(6.3 \times 10^{8}\right.$ spermatozoa) with added fructose $(0.5 \mathrm{ml}$ $0.0111 \mathrm{M}$-fructose solution in $0.25 \mathrm{M}$-sodium phosphate buffer, $\mathrm{pH} 7.4$ ) and without added fructose $(0.5 \mathrm{ml}$ of phosphate buffer alone $) ; 3 \mathrm{ml}$ jackass semen $\left(7.5 \times 10^{8}\right.$ spermatozoa $)$ with $0.2 \mathrm{ml} 0.0555 \mathrm{M}$-fructose solution in $0.25 \mathrm{M}$-sodium phosphate buffer, $\mathrm{pH} 7 \cdot 4$, and without added fructose $(0.2 \mathrm{ml}$ of phosphate buffer alone).

$\mathrm{mg}$, and at the same time, $0.315 \mathrm{mg}$ lactic acid accumulated. The difference, $0.516-0.315=0.201 \mathrm{mg}$, presumably represents that lactic acid which had also been formed from fructose but was subsequently oxidized. Complete oxidation of $0.201 \mathrm{mg}$ lactic acid would have required $149 \mu \mathrm{l} \mathrm{O}$. The actual volume of oxygen which had been taken up in $3 \mathrm{hr}$ by the fructose-containing

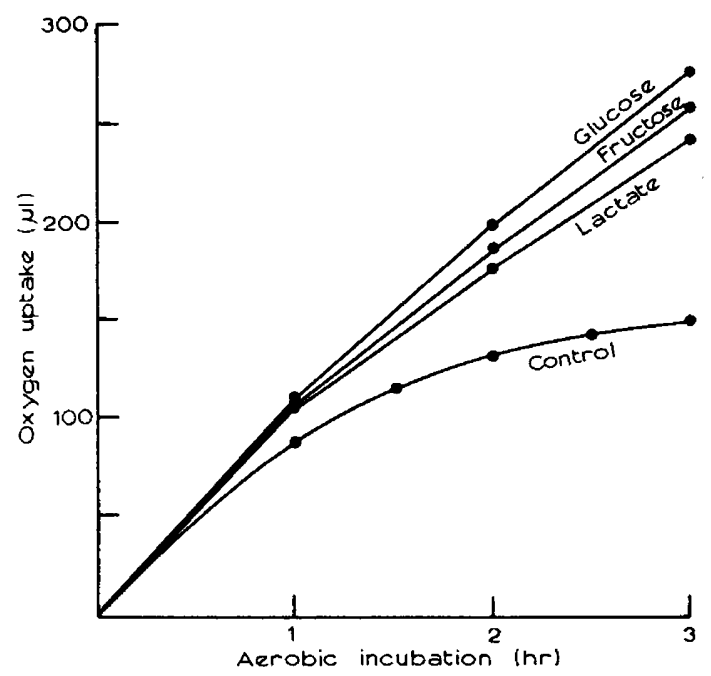

TEXT-Fig. 7. Effect of fructose ( $5 \mathrm{mg})$, glucose $(5 \mathrm{mg})$, and sodium lactate $(5 \mathrm{mg})$ on the respiration of the 'sperm-rich' portion of jackass semen $\left(7 \cdot 1 \times 10^{8}\right.$ spermatozoa/3 ml).

sample of semen was $266 \mu \mathrm{l}$, as compared with $149 \mu \mathrm{l}$ in the control. Presumably, therefore, the oxygen uptake due to lactic acid oxidation was $266-149=117$ $1 \mu \mathrm{O}_{2}$. The $\mathrm{Z}_{\mathrm{O}_{2}}$ values in the fructose-containing and control sample of semen were 11.8 and 6.4 respectively. 
The behaviour of the jackass spermatozoa towards oxidizable substances was studied further by using the 'sperm-rich' or middle portion of ejaculated semen instead of the whole ejaculate. It can be seen from Text-fig. 7 that added lactate or glucose increased the respiration of semen to approximately the same extent as fructose, the $Z_{O_{2}}$ values obtained with the three substrates being 11.14 for lactic acid, 12.90 for glucose, and 11.26 for fructose, as compared with 7.0 for the control sample. In addition to the three substrates mentioned above, the effect of sodium acetate, sorbitol, and glycerol has also been investigated; none of these substances, however, exerted any distinctly stimulatory effect on the rate of oxygen uptake.

EFFECT OF SPERM STORAGE AT $5^{\circ} \mathrm{C}$ ON MOTILITY AND METABOLISM

Text-fig. 8 illustrates the results of an experiment in which the motility and respiration of stallion and jackass spermatozoa was measured in the 'spermrich' portion of ejaculates, diluted with an egg-yolk-containing medium, and

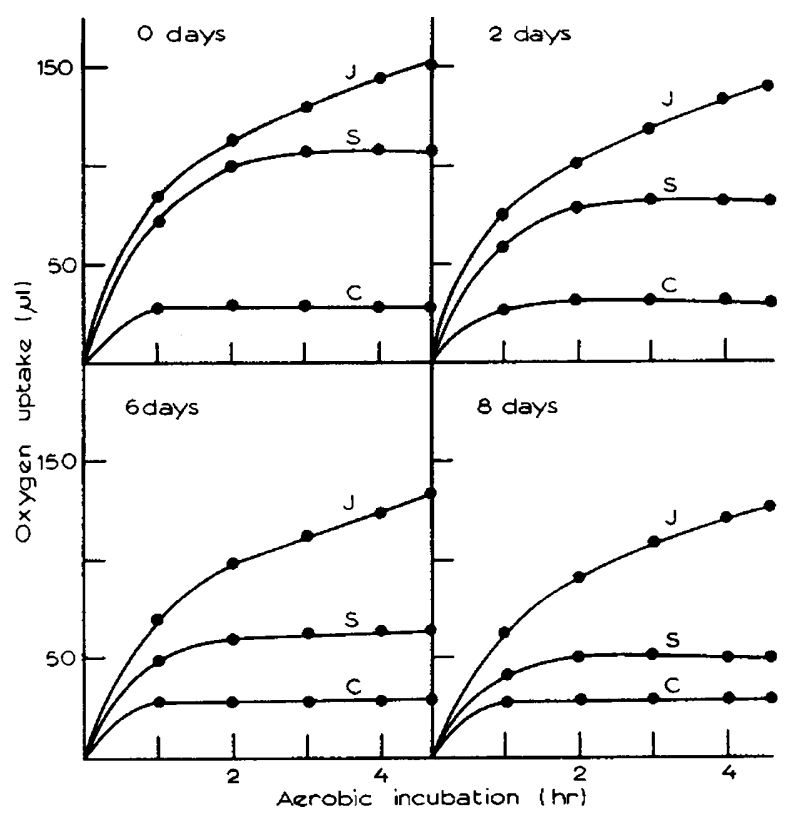

TEXT-FIG. 8. Effect of storage for 0 to 8 days at $5^{\circ} \mathrm{C}$, on the aerobic metabolism of stallion and jackass semen; $\mathrm{S}=$ stallion semen +egg-yolk-glucose diluent; $\mathrm{J}=$ jackass semen t same diluent; $\mathrm{C}=$ control, with the diluent alone.

stored at $5^{\circ} \mathrm{C}$ for varying time intervals. The storage medium consisted of $16 \cdot 6$ $\mathrm{ml}$ fresh egg-yolk, $66.8 \mathrm{ml}$ solution containing $4 \mathrm{~g}$ glucose and $0.2 \mathrm{~g}$ sulphanilamide, and $16.6 \mathrm{ml} \mathrm{1.3 \%}$ solution of sodium bicarbonate. After 'pasteurization' by heating to $59^{\circ} \mathrm{C}$ (for $15 \mathrm{~min}$ ) and subsequent cooling, the medium received a further addition of $0.25 \mathrm{ml}$ solution of 50,000 i.u. streptomycin and $0.5 \mathrm{ml}$ solution of 50,000 i.u. penicillin. Twenty-eight millilitres of the sperm-rich fraction of stallion semen $\left(2.6 \times 10^{8}\right.$ spermatozoa $\left./ \mathrm{ml}\right)$ and $20 \mathrm{ml}$ of a similar fraction from jackass semen $\left(3.6 \times 10^{8}\right.$ spermatozoa $\left./ \mathrm{ml}\right)$ were diluted with the egg-yolk medium to $70 \mathrm{ml}$, so as to achieve in each case a final concentration of 
about $10^{8}$ spermatozoa $/ \mathrm{ml}$. The diluted semen samples were then cooled gradually, in steps of approximately $0.5^{\circ} \mathrm{C} / \mathrm{min}$, to a temperature of $5^{\circ} \mathrm{C}$, and sperm motility and respiration measured after $0,2,4,6$ and 8 days of storage. Although initially, about $90 \%$ of spermatozoa were motile in diluted samples of stallion and jackass semen alike, motility and respiration decreased much more rapidly in stallion than in jackass spermatozoa. After 2, 4,6 and 8 days of storage at $5^{\circ} \mathrm{C}$, the percentage of motile stallion spermatozoa was $60,55,25$ and 18 , respectively, as compared with $80,80,75$ and 60 in the jackass. Respiration, as can be seen from Text-fig. 8, declined at similar rates, that is, much more quickly in stallion than in jackass spermatozoa, with the result that after 8 days of storage, stallion spermatozoa showed only a very small oxygen uptake which was mainly confined to the $1 \mathrm{st} \mathrm{hr}$ of the manometric measurement, whereas jackass spermatozoa continued to exhibit a high respiratory activity throughout the whole period of the manometric measurement.

QUANTITATIVE ASSESSMENT OF THE CONTRIBUTION MADE BY THE DIFFERENT PARTS OF THE MALE REPRODUCTIVE TRACT TOWARDS THE COMPOSITION OF WHOLE SEMEN IN THE JACKASS

When the experiments reported in the previous sections of this paper were concluded, it was decided to kill one of the two jackasses, J2, in order to determine the contribution of the various accessory organs towards the composition of whole semen, by direct chemical analysis of these glands. The general procedure adopted for this purpose was similar to that used by Glover \& Mann

TABLE 2

COMPOSITION OF EJAGULATED SEMEN, EPIDIDYMAL SEMEN, AMPULLAR SEMEN, SEMINAL VESICLE SEGRETION AND PROSTATIG SEGRETION OF THE SAME JAGKASS

\begin{tabular}{l|c|c|c|c}
\hline & Ergothioneine & Citric acid & Lactic acid & $\begin{array}{c}\text { Acid-soluble } \\
\text { phosphorus }\end{array}$ \\
\hline Seminal plasma separated & & & & \\
$\quad$ from the whole ejaculate & $4 \cdot 2$ & $3 \cdot 0$ & $41 \cdot 3$ & $11 \cdot 7$ \\
Semen from the epididymides & $0 \cdot 0$ & $0 \cdot 0$ & $54 \cdot 8$ & $260 \cdot 0$ \\
Semen from the ampullae & $50 \cdot 4$ & $0 \cdot 0$ & $52 \cdot 8$ & $32 \cdot 7$ \\
Seminal vesicle secretion & $2 \cdot 0$ & $72 \cdot 0$ & $319 \cdot 0$ & \\
Prostatic secretion & $0 \cdot 0$ & 0.0 & 81.2 & \\
\hline
\end{tabular}

An ejaculate $(92 \mathrm{ml}, 200,000$ spermatozoa/ $/ \mathrm{l})$ was collected from the jackass J2. Four days later the animal was killed, and the contents of the various accessory organs removed for analysis; the results are expressed in $\mathrm{mg} / 100 \mathrm{ml}$.

(1954) in their study of boar semen and accessory secretions. Four days prior to slaughter, a complete ejaculate was collected from the animal for analysis. Then, after slaughter, the male reproductive tract was removed and the contents of the epididymides and ampullae, as well as the viscous secretion of the seminal vesicles, and the clear prostatic secretion, were collected for analysis. The results, which are given in Table 2 , show that in ejaculated semen collected 4 days prior to slaughter, the concentration of ergothioneine was $4 \cdot 2 / 50 \cdot 4=$ $8.3 \%$ of that found in the ampullae, and the concentration of citric acid 
$3 \cdot 0 / 72 \cdot 0=4 \cdot 1 \%$ of that found in the seminal vesicles. Lactic acid, unlike ergothioneine and citric acid, was not limited to any one gland, but was distributed throughout all parts of the reproductive tract. By far the highest concentration of it, however, was encountered in the seminal vesicle secretion, namely, $319 \mathrm{mg} / 100 \mathrm{ml}$. This result further confirms that the high lactic acid content of the 'post-sperm' fraction is derived from the seminal vesicles.

\section{DISCUSSION}

The results obtained in the present study fall into four groups. The first concerns the general characteristics of stallion and jackass semen. It was shown that the two species resemble each other as regards the presence of certain constituents such as ergothioneine and citric acid. This similarity was further underlined by the second group of results, obtained first by the analyses of the 'pre-sperm', 'sperm-rich' and 'post-sperm' fractions of ejaculated semen, and next by direct examination of the contents removed at autopsy, from the epididymides, ampullae, and seminal vesicles. Both with respect to the occurrence of the three 'fractions' in ejaculated semen, as well as with respect to the presence of ergothioneine and citric acid as regular seminal constituents, findings in stallion and jackass semen resemble those of the boar. Whereas in the boar, however, both ergothioneine and citric acid are contributed together by the seminal vesicles, in the stallion and jackass, ergothioneine is derived chiefly from the ampullae, and citric acid from the seminal vesicles.

The main metabolic characteristics of stallion and jackass semen are on the whole, analogous to those of the boar. This is evident from the third group of experimental results concerning the levels of anaerobic and aerobic fructolysis, as well as respiration, in stallion and jackass semen. Like those of the boar, the spermatozoa of the stallion and jackass are comparatively ineffective 'anaerobes' and the rate at which they utilize fructose anaerobically seems, on the whole, to be even lower than in the boar. On the other hand, stallion and jackass spermatozoa, like those of the boar, are highly effective 'aerobes', and their respiration rate, particularly in the presence of added substrates, equals that of other species such as ram or bull. In jackass, however, the rate of aerobic sperm metabolism is higher than in the stallion. As with boar semen, the oxygen uptake of stallion and jackass semen is not all due to the spermatozoa, but is contributed, particularly during the early period of manometric measurements, by the seminal plasma.

As regards sperm survival under storage conditions in vitro, stallion and jackass semen differ markedly from each other. This difference is borne out clearly by the last group of experimental results which were obtained with the 'sperm-rich' fraction of stallion and jackass semen, diluted with an 'egg-yolk medium' and stored for several days at $5^{\circ} \mathrm{C}$. The sperm motility and respiratory activity of the stallion semen were shown to decrease during storage much more rapidly than in jackass semen. The explanation may be sought, perhaps, in a greater 'resistance' of jackass spermatozoa to environmental factors, possibly linked in some way with structural peculiarities of the sperm cell. It is known that jackass spermatozoa differ morphologically from those of the stallion in several respects; the jackass spermatozoon is slightly longer, its head more 
rounded, and in general, it resembles more that of bull, ram, rabbit or boar (Nishikawa, 1959). Furthermore, the two species differ in certain respects, in so far as their reproductive organs are concerned; both species possess ampullary glands, but these are much larger in the jackass than in the stallion (Plate 1). Consequently, the storage capacity of the ampullae in the jackass is also distinctly greater than in the stallion.

\section{ACKNOWLEDGMENTS}

One of us (C. S. M.) wishes to acknowledge with thanks the grants received from the Greek Ministries of Agriculture and Coordination, and the United States Operation Mission (Greece).

\section{REFERENGES}

Aalbers, J. G., Mann, T. \& Polge, C. (1961) Metabolism of boar semen in relation to sperm motility and survival. 7. Reprod. Fertil. 2, 42.

Barker, S. P. \& Summerson, W. H. (1941) The colorimetric determination of lactic acid in biological material. 7. biol. Chem. 138, 535.

Dawson, R. M. C., Mann, T. \& White, I. G. (1957) Glycerylphosphorylcholine and phosphorylcholine in semen, and their relation to choline. Biochem. $\mathbf{7 . 6 5 , 6 2 7 .}$

Glover, T. \& ManN, T. (1954) On the composition of boar semen. 7. agric. Sci. 44, 353.

KrNG, E. J. (1946) Micro-analysis in medical biochemistry. Churchill, London.

Krng, T. E. \& MANN, T. (1959) Sorbitol metabolism in spermatozoa. Proc. roy. Soc. B, 151, 226.

Leone, E. (1954) Ergothioneine in the equine ampullar secretion. Nature, Lond. 174, 404.

MaNn, T. (1946) Studies on the metabolism of semen. 3. Fructose as a normal constituent of seminal plasma. Site of formation and function of fructose in semen. Biochem. 7. 40, 481.

Mann, T. (1948) Fructose content and fructolysis in semen. Practical application in the evaluation of semen quality. 7. agric. Sci. 38, 323.

Mann, T., Leone, E. \& Polge, C. (1956) The composition of the stallion's semen. 7. Endocrin. 13, 279.

Mann, T., Short, R. V., Walton, A., Archer, R. K. \& Miller, W. G. (1957) The 'tail-end sample' of stallion semen. 7 . agric. Sci. 49, 301 .

Nishikawa, Y. (1959) Studies on reproduction in horses, p. 310. Japan Racing Association, Tokyo.

Umbreit, W. W., Burris, R. H. \& Stauffer, J. F. (1957) Manometric techniques. Burgess, Minneapolis. 


\section{PLATE 1}

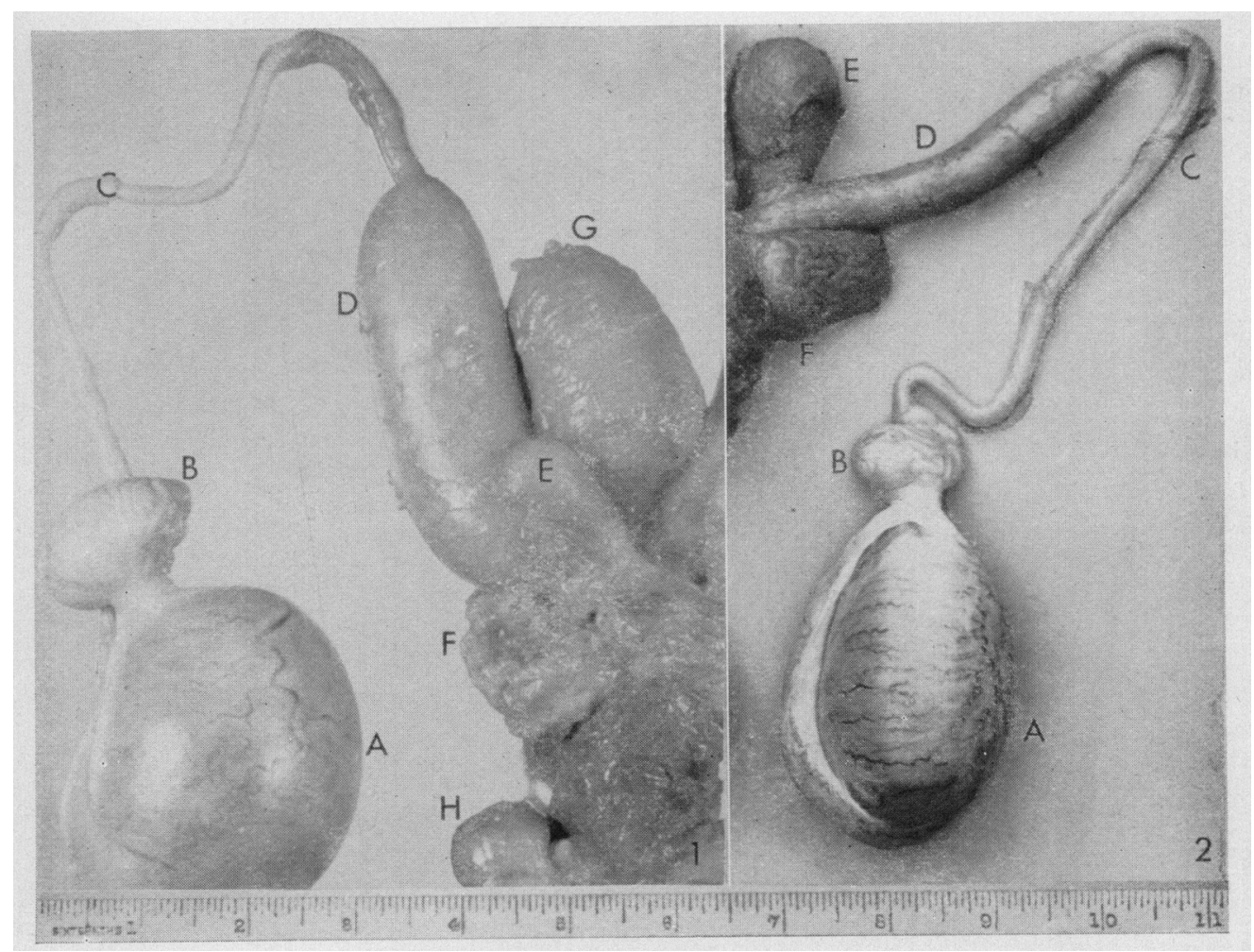

Part of the reproductive tract of jackass (Fig. 1) and stallion (Fig. 2). A = testis; $\mathrm{B}=$ epididymis $\mathrm{C}=$ vas deferens $\mathrm{D}=$ ampulla $; \mathrm{E}=$ seminal vesicle $; \mathrm{F}=$ prostate $;$ $\mathrm{G}=$ bladder; $\mathrm{H}=$ Cowper's gland. Scale in inches. 